\title{
Supercritical fluid carbon dioxide extraction of Nigella sativa (black cumin) seeds using taguchi method and full factorial design
}

\author{
Rinaldi Salea', Edward Widjojokusumo ${ }^{1}$, Apriliana Wahyu Hartanti ${ }^{2}$, Bambang Veriansyah' ${ }^{1}$ and Raymond R Tjandrawinata ${ }^{1,2^{*}}$ \\ *Correspondence: raymond@dexa-medica.com \\ ${ }^{1}$ Advanced Technology Development, Dexa Laboratories of Biomolecular Sciences (DLBS), Industri Selatan V, \\ Block PP no. 7, Jababeka Industrial Estate II, Cikarang, West Java 17550, Indonesia. \\ ${ }^{2}$ Metabolic Engineering, Dexa Laboratories of Biomolecular Sciences (DLBS), Industri Selatan V, Block PP no. 7, \\ Jababeka Industrial Estate II, Cikarang, West Java 17550, Indonesia.
}

\begin{abstract}
Optimum condition for Nigella sativa seeds oil and its bioactive compound, thymoquinone (TQ) using supercritical fluid carbon dioxide extraction (SCFE-CO $)$, were investigated. The optimization process was performed with Taguchi method and full factorial design (FFD) under the following condition: pressure (150, 200 and 250 bar), temperatures $\left(40,50\right.$ and $\left.60^{\circ} \mathrm{C}\right)$ and carbon dioxide $\left(\mathrm{CO}_{2}\right)$ flowrate $(10,15$ and $20 \mathrm{~g} / \mathrm{min})$, in which solvent to feed (SF) ratio was set constant at 24 . The highest yield of Nigella sativa seeds oil from SCFE- $\mathrm{CO}_{2}$ process with FFD method was $12 \%$ at $250 \mathrm{bar}, 60^{\circ} \mathrm{C}$ and $20 \mathrm{~g} / \mathrm{min}$. Whereas Taguchi method was performed at $250 \mathrm{bar}, 50^{\circ} \mathrm{C}, 10 \mathrm{~g} / \mathrm{min}$ with oil yield $11.9 \%$. The highest thymoquinone content in Nigella sativa seeds oil from both experimental design was achieved through SCFE- $\mathrm{CO}_{2}$ extraction condition at $150 \mathrm{bar}, 60^{\circ} \mathrm{C}$ and $20 \mathrm{~g} / \mathrm{min}$ with thymoquinone content $20.8 \mathrm{mg} / \mathrm{ml}$. In addition, conventional methods such as high pressure soxhlet with liquid $\mathrm{CO}_{2}$, n-hexane soxhlet and percolation with ethanol were performed with oil yield 5.8\%, 19.1\% and 12.4\%; and thymoquinone content $8.8 \mathrm{mg} / \mathrm{g}$ oil, $6.3 \mathrm{mg} / \mathrm{g}$ oil and $5.0 \mathrm{mg} / \mathrm{g}$ oil, respectively. The analysis of variance (ANOVA) with 95\% confidence interval, indicates effect of pressure on Nigella sativa seeds oil yield and thymoquinone content from SCFE- $\mathrm{CO}_{2}$ process. The oil was then evaluated for its activity. The antibacterial activity of the oil from Taguchi Method, shows that all samples were unable to inhibit Escherichia coli O157 and Salmonella typhimurium. For other pathogenic bacterias, all samples show similar inhibition at concentration 10\% oil for MRSA, 3\% oil for Stapylococcus aureus and 3\% oil for Bacillus subtilis.
\end{abstract}

Keywords: SCFE- $\mathrm{CO}_{2}$, Nigella sativa, taguchi method, full factorial design, thymoquinone, antibacterial activity

\section{Introduction}

Nigella sativa (black cumin) seeds, a dicotyledon of Ranunculaceae family, have been used for thousands years as spice and food preservative [1-3]. Black cumin is an annual herbaceous plant widely grown in Mediterranean countries, Middle East, Eastern Europe and Western Asia. In Middle East, Northern Africa and India, it has been used traditionally for centuries to treat asthma, cough, bronchitis, headache, rheumatism, fever, influenza and eczema [3,4]. It has also been used as anti-histamine, anti-diabetes and anti-inflammatory. The oil and seed constituents, in particular thymoquinone (TQ), have shown medicinal properties in treatment and prevention of various diseases [5-7, 10-12]. They have various potent activities such as anti-inflammatory [3]; anti-oxidant [1,2,4]; anti-cancer $[6,7,10]$, etc. In addition, they also expressed anti-microbial properties toward different microbes $[\mathbf{8}, \mathbf{9}]$.

Supercritical fluid extraction (SCFE) has many advantages compared to conventional extraction methods such as its environmentally compatible fluids, low temperature, shorter extraction time and ease separation of solute from supercritical fluid solvent by simple expansion. Moreover, this extraction does not leave any trace of organic solvent [13-17]. The most frequently employed supercritical solvent is carbon dioxide $\left(\mathrm{CO}_{2}\right)$. It has low toxicity, good safety, cheap, abundant in pure form (food grade) and low critical temperature and pressure $[13,14,16,17]$.

Optimization process is critical as various parameters may potentially affect the SCFE process. The optimum condition can be achieved by investigating multiple factors in all possible conditions [18]. This condition was considered achieved when high yield of oil and high content of thymoquinone was obtained. The objective of this present research is comparing Nigella sativa seeds oil extracted by SCFE process using two different experimental designs, Taguchi's method and full factorial design. Other conventional extraction methods were also performed as comparison.

\section{Materials and methods}

Nigella sativa seeds were imported from Arab by "Intisari Herbal" supplier (Solo, Indonesia). Prior to the extraction process, all dried plant materials were grounded in milling machine (China) with stainless filter mess \#10. Particle distribution of grounded raw material is shown at (Table 1). Moisture content was determined using H83 Halogen Moisture Analyzer (loss on drying 6.87\% ) and Volumetric KF Titrator V30 (water content 5.99\%).

Food grade liquid carbon dioxide (purity $99.99 \%$ ) was supplied in cylinder tube by PT. Inter Gas Mandiri (Cikarang, Indonesia); Analytical grade $\mathrm{n}$-hexane was purchased from 
Salea et al. Biochemical Compounds 2013,

Table 1. Particle distribution of grounded raw material.

\begin{tabular}{cccccc}
\hline \multicolumn{2}{c}{ Sieves } & $\mathrm{W}_{\text {before }}($ gram) & $\mathrm{W}_{\text {after }}(\mathrm{gram})$ & $\mathrm{W}_{\text {after }}-\mathrm{W}_{\text {before }}$ (gram) & $\%$ \\
\hline 2 & $\mathrm{~mm}$ & 345.3 & 345.3 & 0 & 0 \\
1 & $\mathrm{~mm}$ & 316.9 & 324.8 & 7.9 & 77.26 \\
500 & $\mu \mathrm{m}$ & 279.4 & 280.2 & 0.8 & 7.824 \\
250 & $\mu \mathrm{m}$ & 259.1 & 259.9 & 0.8 & 7.824 \\
180 & $\mu \mathrm{m}$ & 242.0 & 242.4 & 0.4 & 3.912 \\
125 & $\mu \mathrm{m}$ & 254.3 & 254.3 & 0 & 0 \\
63 & $\mu \mathrm{m}$ & 242.0 & 242.0 & 0 & 0 \\
45 & $\mu \mathrm{m}$ & 244.5 & 244.6 & 0.1 & 0.978 \\
0 & - & 358.1 & 358.1 & 0 & 0 \\
\hline
\end{tabular}

Table 2. Standard $\mathrm{L}_{9}$ orthogonal arrays.

\begin{tabular}{c|ccc}
\hline \multirow{2}{*}{ Exp. No. } & \multicolumn{3}{|c}{ Independent Variables } \\
\cline { 2 - 4 } & A & B & C \\
\hline 1 & 1 & 1 & 1 \\
2 & 1 & 2 & 2 \\
3 & 1 & 3 & 3 \\
4 & 2 & 1 & 2 \\
5 & 2 & 2 & 3 \\
6 & 2 & 3 & 1 \\
7 & 3 & 1 & 3 \\
8 & 3 & 2 & 1 \\
9 & 3 & 3 & 2 \\
\hline
\end{tabular}

Table 3. Parameters and levels used in both experimental design.

\begin{tabular}{c|ccc}
\hline \multirow{2}{*}{ LEVEL } & \multicolumn{3}{|c}{ FACTOR } \\
\cline { 2 - 4 } & Pressure (bar) & Temperature $\left({ }^{\circ} \mathbf{C}\right)$ & $\mathrm{CO}_{2}$ Flowrate $(\mathrm{gr} / \mathbf{m i n})$ \\
\cline { 2 - 4 } & $\mathbf{A}$ & $\mathbf{B}$ & $\mathrm{C}$ \\
\hline $\mathbf{1}$ & 150 & 40 & 10 \\
$\mathbf{2}$ & 200 & 50 & 15 \\
$\mathbf{3}$ & 250 & 60 & 20 \\
\hline
\end{tabular}

Merck, Darmstadt, Germany; Technical grade (96\%) ethanol was obtained from PT. Brataco, Bekasi, Indonesia and thymoquinone (purity 99.9\%) was purchased from SigmaAldrich Co., St. Louis, Missouri, USA.

\section{Design of experiment}

\section{Taguchi method}

The Taguchi method utilizes orthogonal array design (OAD) to study a large number of parameters with a small number of experiments. It significantly reduces number of experimental configurations to be studied without affecting the quality of results [19] and maintain the experimental cost at minimum level [20]. Taguchi Method was employed a special set of OAD in each number of experimental conditions to systematically look for the favorable operating conditions [18]. In this study, the following parameters are considered in the SCFE- $\mathrm{CO}_{2}$ process: pressure (A), temperature $(\mathrm{B})$ and $\mathrm{CO}_{2}$ flowrate $(\mathrm{C})$, and each parameter consists with three levels (values). Thus, the $L_{9}$ orthogonal arrays improved by Taguchi method as shown in (Table 2), was chosen to determine the experimental design. The quality of results were measured by the signal-to-noise
$(\mathrm{S} / \mathrm{N})$ ratio with three different characteristic of target values: "larger is better", "smaller is better" or "nominal is better" $[\mathbf{1 8 , 2 0 ]}$. Since purpose of this study was the highest oil yield and TQ content, target values of "larger is better" was chosen. In this study, interactions among variables were not considered and focus was placed on the main effects of three parameters.

\section{Full factorial design (FFD)}

FFD is the most basic structures experimental design. In FFD, responses are measured at all combinations of experimental factor levels [21]. Each experimental condition is called a "run" and each run represents variation of one variable. Each response will be measured for an observation. The entire set of runs is the "design". Since, we consider three parameters with three levels, the total run with full factorial design is $3^{3}$ (27) number of trials. The variation levels for parameters is shown in (Table 3).

\section{Supercritical carbon dioxide extraction}

The supercritical carbon dioxide (SCFE-CO2) extraction was carried out using supercritical fluid extractor with $\mathrm{CO}_{2}$ cycle system (KIST-Korea) as shown in (Figure 1). The extractor vessel with $2 \times 1000 \mathrm{ml}$ capacity was loaded with $100 \mathrm{~g}$ powdered material of Nigella sativa. Food grade liquid $\mathrm{CO}_{2}$ was delivered to extraction vessel using high pressure pump (Thar, USA). Extraction pressure was varied from 150-250 bar and temperature $40-60^{\circ} \mathrm{C}$. The pressure in the extraction vessel was controlled by back pressure regulator (Tescom, USA). Heat exchangers (Lab. Companion, USA) were provided in system to maintain temperature in the extractor and separator vessel. $\mathrm{CO}_{2}$ flow rate was varied from 10 to $20 \mathrm{~g} / \mathrm{min}$ for static extraction time of 60 minutes (fixed for all the extractions) and followed by dynamic extraction time (120, 160 and 240 $\mathrm{min}$ ) that had been determined based on each $\mathrm{CO}_{2}$ flowrate. Therefore, the solvent to feed (SF) ratio was constant at 24 . Extract was collected every 20 min (cummulated) until dynamic extraction time finished. Yield of extract was determined as summation of extract from the experiments.

\section{High pressure soxhlet (HPS) extraction}

About $50 \mathrm{~g}$ of powdered Nigella sativa seeds were submitted to high pressure soxhlet extraction (KIST-Korea) with $\mathrm{CO}_{2}$ liquid as solvent. The operating condition for HPS extraction is at boiler temperature $35^{\circ} \mathrm{C}$, chiller temperature $-5^{\circ} \mathrm{C}$ ( $\mathrm{Lab}$. Companion, USA), pressure $40-50$ bar, $\mathrm{CO}_{2}$ cycle-rate $5 \mathrm{~min}$ and extraction time 7 hours. The remaining extract was considered as experiment yield.

\section{Soxhlet $\mathbf{n}$-hexane extraction}

About $50 \mathrm{~g}$ of powdered Nigella sativa seeds were extracted with $600 \mathrm{ml} \mathrm{n}$-hexane (ratio 12:1). Operating condition is at boiler temperature $100^{\circ} \mathrm{C}$, chiller temperature $-5^{\circ} \mathrm{C}$ (Lab. Companion, USA), pressure 1 bar and extraction time 6 hours. The extract was filtered and then evaporated to separate 
Salea et al. Biochemical Compounds 2013,

Table 4. Experiment results for SCFE-CO2 process of Nigella sativa with Taguchi Method.

\begin{tabular}{ccccccc}
\hline Run & $\begin{array}{c}\text { Pressure } \\
(\mathbf{b a r})\end{array}$ & $\begin{array}{c}\text { Temperature } \\
(\mathbf{C})\end{array}$ & $\begin{array}{c}\mathrm{CO}_{2} \text { flowrate } \\
(\mathbf{g p m})\end{array}$ & $\begin{array}{c}\text { Yield } \\
\text { Total }(\%)\end{array}$ & $\begin{array}{c}\text { Yield Oil } \\
(\%)\end{array}$ & $\begin{array}{c}\text { TQ } \\
(\mathbf{m g} / \mathbf{g} \text { oil) }\end{array}$ \\
\hline 1 & 150 & 40 & 10 & 9.5 & 8.9 & 11.9 \\
2 & 150 & 50 & 15 & 9.1 & 8.6 & 15.1 \\
3 & 150 & 60 & 20 & 6.1 & 4.8 & 20.8 \\
4 & 200 & 40 & 15 & 10.3 & 9.5 & 10.5 \\
5 & 200 & 50 & 20 & 11.4 & 10.4 & 10.3 \\
6 & 200 & 60 & 10 & 12.5 & 10.6 & 11.0 \\
7 & 250 & 40 & 20 & 11.6 & 10.7 & 9.1 \\
8 & 250 & 50 & 10 & 13.1 & 11.9 & 9.5 \\
9 & 250 & 60 & 15 & 12.8 & 12.0 & 10.5 \\
\hline
\end{tabular}

Table 5. Antibacterial activity of Nigella sativa oil with disc diffusion assay method.

\begin{tabular}{c|ccccc}
\hline \multirow{2}{*}{ Run } & \multicolumn{5}{|c}{ Average of inhibition zone (cm) against pathogen bacteria } \\
\cline { 2 - 6 } & $\begin{array}{c}\text { EC O157 } \\
(\mathbf{1 0 0 \% ~ N S )}\end{array}$ & BS (3\% NS) & ST (100\% NS) & SA (3\% NS) & MA (10\% NS) \\
\hline 1 & - & 2.50 & - & 0.60 & 0.20 \\
2 & - & 2.50 & - & 0.63 & 0.25 \\
3 & - & 2.80 & - & 0.60 & 0.35 \\
4 & - & 1.00 & - & 0.20 & 0.20 \\
5 & - & 2.15 & - & 0.30 & 0.20 \\
6 & - & 0.90 & - & 0.30 & 0.30 \\
7 & - & 0.75 & - & 0.30 & 0.15 \\
8 & - & 0.95 & - & 0.30 & 0.15 \\
9 & - & 1.00 & - & 0.30 & 0.15 \\
\hline
\end{tabular}

Note:

NS : Nigella sativa oil

EC O157 : E. coli O157

BS : Bacillus subtilis

ST : Salmonella typhimurium

SA : Stapylococcus aureus

MA : Methicillin- Resistance Staphylococcus Aureus (MRSA)

- $\quad$ : not show inhibition

the organic solvent ( $\mathrm{n}$-hexane). The remaining extract was considered as experiment yield.

\section{Solvent extraction (ethanol 96\%) with percolator}

About $200 \mathrm{~g}$ of powdered Nigella sativa seeds were extracted with $2700 \mathrm{ml}$ Ethanol (96\%, Technical Grade). Operating condition for percolation process is at pressure solvent pump (HKS, Korea) 10 bar, room temperature with solvent flowrate at $180 \mathrm{ml} / \mathrm{min}$ and the extraction time 7 hours. The extract was filtered and then evaporated to separate the organic solvent (ethanol). The remaining extract was considered as experiment yield.

\section{Gas chromatography analysis}

Thymoquinone analysis was performed using Perkin-Elmer Gas Chromatography Clarus 680 with Flame Ionized Detector (FID) detector. The entire analyses were carried out by Elite- 5 column ( $30 \mathrm{~m} \times$ ID $0.25 \mathrm{~mm}$, DF $0.25 \mu \mathrm{m} ; \mathrm{T}=60-330^{\circ} \mathrm{C}$ ). Oven temperature was increased from $95^{\circ} \mathrm{C}$ with ramp $20^{\circ} \mathrm{C} / \mathrm{min}$ to $280^{\circ} \mathrm{C}$ and held isothermal for $5 \mathrm{~min}$. The injector and detector temperature were maintained at $220^{\circ} \mathrm{C}$ and $240^{\circ} \mathrm{C}$, respectively. Sample solution was prepared with concentration of 4000 ppm in 2-propanol (chromAR). The injection volume was 1.0 $\mu \mathrm{l}$ with a split ratio at 10:1. Flowrate carrier nitrogen $\left(\mathrm{N}_{2}\right)$ gas at $1.0 \mathrm{ml} / \mathrm{min}$, Hidrogen $\left(\mathrm{H}_{2}\right)$ at $45.0 \mathrm{ml} / \mathrm{min}$ and compress air UHP (Ultra High Purity) at $450.0 \mathrm{ml} / \mathrm{min}$.

\section{Anti-microbial analysis}

Bacterial species used in this study were Escherichia coli O157, Bacillus subtilis ATCC 6633, Salmonella typhimurium ATCC 13311, Stapylococcus aureus ATCC 6538 and Methicillin Resistant Staphylococcus Aureus (MRSA). Antibacterial activity was determined by disc diffusion assay. Nigella sativa seeds oil was dissolved in dimethylsulphoxide (DMSO; Merck, Germany) to reach final concentration 3\%, 5\%, 10\% and $100 \%$ (without dilution) and sterilized using filtration method with $0.22 \mu \mathrm{m}$ membrane filters (Iwaki, Japan). The medium used were MHA (Mueller-Hinton Agar) supplied from Merck (Germany). The 6 $\mathrm{mm}$ diameter disc (Whatman, USA) were impregnated with $20 \mu \mathrm{l}$ of the oil and placed on inoculated agar $\left(10^{6} \mathrm{CFU} / \mathrm{ml}\right.$ of bacterial). Ciprofloxacin $0.2 \mathrm{mg} / \mathrm{ml}$ was used as positive reference standards to determine the sensitivity of tested microbial species. Control test was dissolved in 100\% DMSO and showed no inhibition of microbial growth. The inoculated plates were incubated at $37^{\circ} \mathrm{C}$ for $24 \mathrm{~h}$ for bacterial species growth. Antibacterial activity was evaluated by measuring zone of inhibition against those bacterial species. All inhibition assays and controls were carried out triplicate.

\section{Statistical analysis}

The data obtained from supercritical carbon dioxide extraction were subjected to analysis of variance (ANOVA) to determine significant difference among all extract yield. P-value less than 0.05 were considered significant. All statistical analysis were performed using MINITAB v.15 (Minitab Inc., USA) statistical software package.

\section{Results and Discussion}

(Table 4 and 5) show the yield and Thymoquinone (TQ) content of Nigella sativa seeds oil extracted by SCFE process using Taguchi Method and FFD, respectively.

\section{Taguchi method}

(Figure $2 a$ and $\mathbf{2 b}$ ) show main effect plots for $\mathrm{S} / \mathrm{N}$ ratio between oil yield and TQ content in Nigella sativa with different variables, including pressure ( $\mathrm{P}, 150-250 \mathrm{bar})$, temperature $\left(\mathrm{T}, 40-60^{\circ} \mathrm{C}\right)$ and $\mathrm{CO}_{2}$ flowrate $(10-20 \mathrm{~g} / \mathrm{min})$. Main effect plots were determined based on signal-to-noise $(\mathrm{S} / \mathrm{N})$ ratio which express the scatter around a target value. The larger the ratio means the smaller the scatter. Noise factors are viewed as the cause of variability in investigated responses. The $\mathrm{S} / \mathrm{N}$ ratio measures level of performance and effects of noise factors on performance. According to Taguchi Method, 


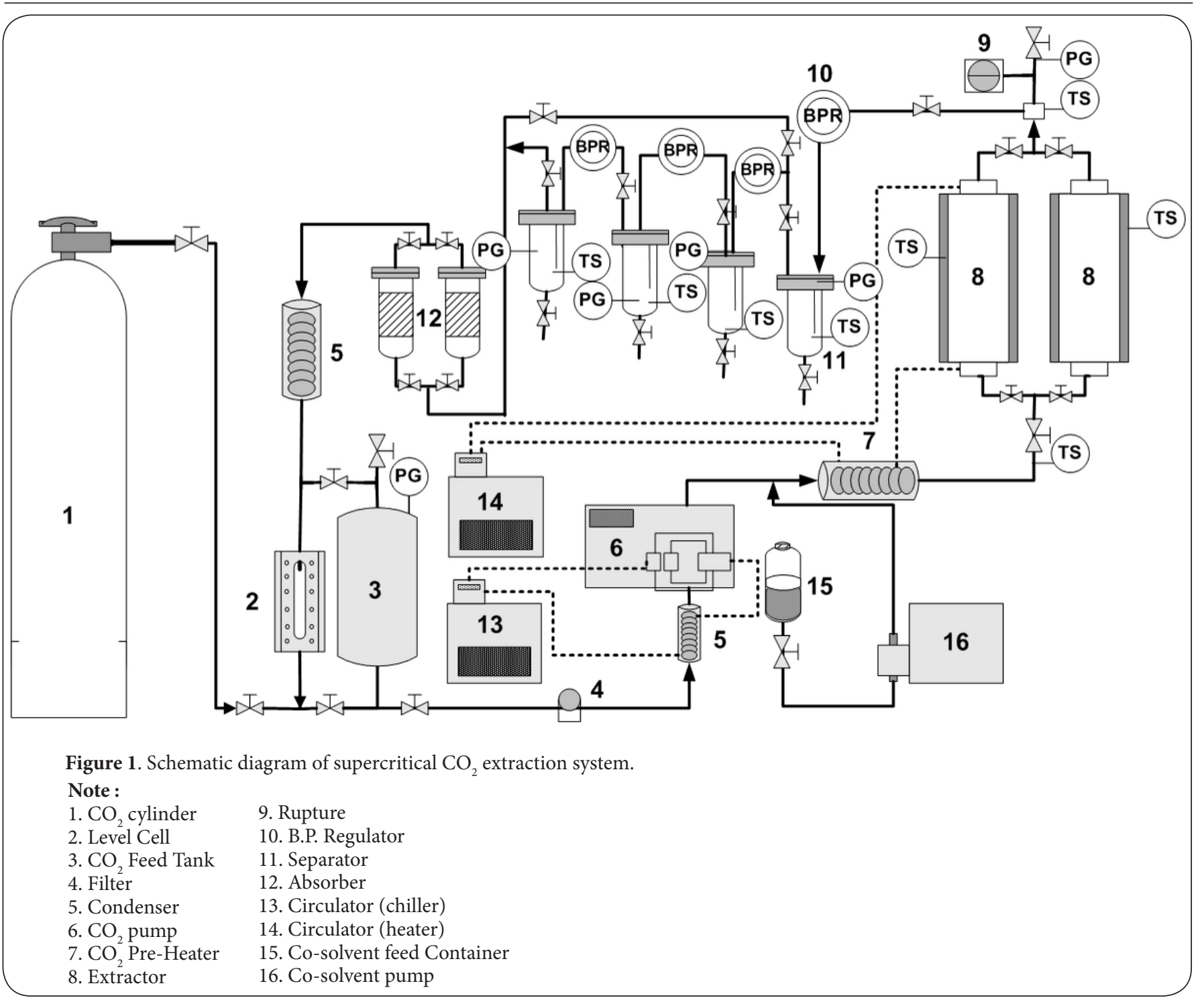

the optimum conditions for Nigella sativa seeds oil yield were at $\mathrm{P}=250 \mathrm{bar}, \mathrm{T}=50^{\circ} \mathrm{C}$ and $\mathrm{CO}_{2}$ flowrate $=10 \mathrm{~g} / \mathrm{min}$ (Figure 2a). Whereas the optimum conditions for thymoquinone content were obtained at $\mathrm{P}=150 \mathrm{bar}$ and $\mathrm{T}=60^{\circ} \mathrm{C}$ with $\mathrm{CO}_{2}$ flowrate $20 \mathrm{~g} / \mathrm{min}$.

The antibacterial activity of Nigella sativa seeds oil were tested with disc diffusion assay method on several strains of bacteria such as Escherichia coli O157, Bacillus subtilis, Salmonella typhimurium, Stapylococcus aureus and MethicillinResistant Staphylococcus Aureus (MRSA) (Table 5). Based on the results of antibacterial activity test, all samples did not inhibit E. coli $\mathrm{O} 157$ and Salmonella typhimurium even without oil dilution treatment. For other pathogenic bacterial, all samples show similar inhibition (insignificant difference) at $10 \%$ oil for MRSA, 3\% oil for Stapylococcus aureus and 3\% oil for Bacillus subtilis. All samples show a better inhibition against Gram-positive bacteria compared to Gram-negative bacteria.
The higher resistance of Gram-negative bacteria to external agents is due to the presence of lipopolysaccharides in their outer membranes, which make them inherently resistant to antibiotics, detergents and hydrophilic dyes.

\section{Full factorial design (FFD)}

FFD requires more experimental points, however it can provide more information on the effect of various combinations. (Table 6) show various combination factors including pressure ( $\mathrm{P}, 150-250$ bar), temperature ( $T, 40-60$ bar) and $\mathrm{CO}_{2}$ flowrate (10-20 $\mathrm{g} / \mathrm{min}$ ). The optimum conditions to obtain high oil yield was at 250 bar and $60^{\circ} \mathrm{C}$. All three level of $\mathrm{CO}_{2}$ flowrate at this condition yield similar results $12 \%$ of Nigella sativa seeds oil. Therefore, $20 \mathrm{~g} / \mathrm{min}$ was considered as optimum level for $\mathrm{CO}_{2}$ flowrate This result is different compared to Taguchi method at $250 \mathrm{bar}, 50^{\circ} \mathrm{C}$ and $10 \mathrm{~g} / \mathrm{min}$ with oil yield $11.9 \%$. However, the difference between these two optimum condition is 


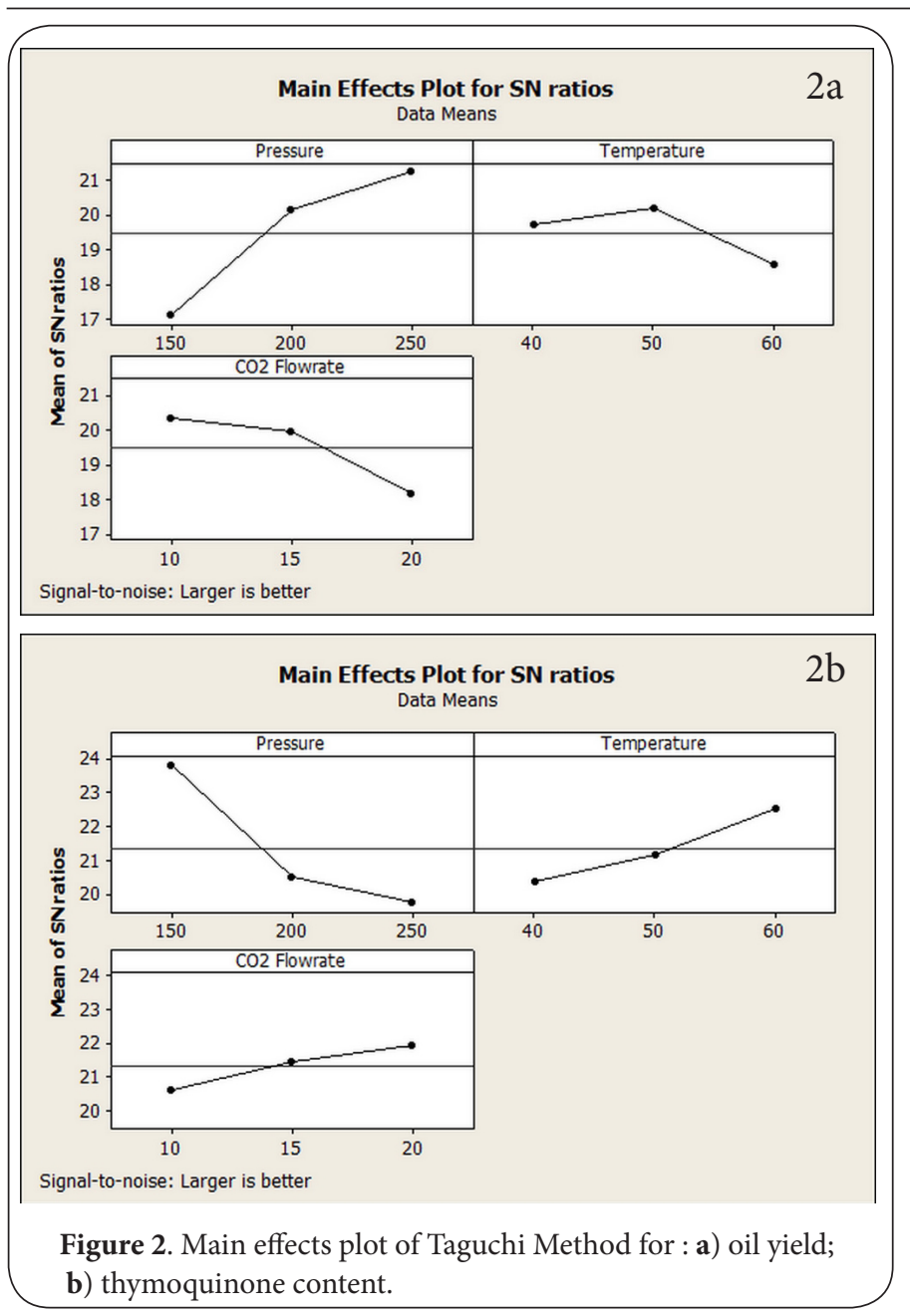

insignificant $(0.1 \%)$. For TQ content, both experimental designs gave similar results at $20.8 \mathrm{mg} / \mathrm{g}$ oil. Therefore, taguchi method was able to simplify the experimental procedure without affecting the quality of results.

Generally, higher pressure at isothermal conditions result an increase in solvent density, subsequently the solvent power and solubility of compounds. As the density increased, the distance between the molecules decreased; the interaction between the compounds and $\mathrm{CO}_{2}$ increased; which leads to increase compounds solubility in $\mathrm{CO}_{2}$. Therefore, increase in pressure will also accelerate mass transfer analytes and solvent in supercritical extractor vessel system and increase the extraction yield of Nigella sativa seeds oil. Solubility of solutes in SCFE- $\mathrm{CO}_{2}$ is affected by solvent density and volatility of solutes which depend on temperature in opposing ways. Higher temperatures increase the volatility of solutes and improve their solubility and extraction. On the other hand, at a given pressure, density of supercritical $\mathrm{CO}_{2}$ decreases with increase in temperature, reduction in solvation power of $\mathrm{CO}_{2}$ and thus reduction in solubility and extraction efficiency [23-25].

The significance of each independent variable determined
Table 6. Experiment results for SCFE-CO2 process of N. sativa with Full Factorial Design.

\begin{tabular}{|c|c|c|c|c|c|c|}
\hline Run & $\begin{array}{l}\text { Pressure } \\
\quad \text { (bar) }\end{array}$ & $\begin{array}{c}\text { Temperature } \\
\text { (C) }\end{array}$ & $\begin{array}{c}\mathrm{CO}_{2} \text { flowrate } \\
(\mathrm{gpm})\end{array}$ & $\begin{array}{l}\text { Yield Total } \\
\text { (\%) }\end{array}$ & $\begin{array}{c}\text { Yield } \\
\text { Oil } \\
(\%)\end{array}$ & $\begin{array}{c}\text { TQ } \\
\text { (mg/g oil) }\end{array}$ \\
\hline 1 & 150 & 40 & 10 & 9.5 & 8.9 & 11.9 \\
\hline 2 & 150 & 40 & 15 & 9.2 & 8.8 & 9.4 \\
\hline 3 & 150 & 40 & 20 & 8.6 & 8.2 & 9.4 \\
\hline 4 & 150 & 50 & 10 & 9.7 & 8.7 & 8.3 \\
\hline 5 & 150 & 50 & 15 & 9.1 & 8.6 & 15.1 \\
\hline 6 & 150 & 50 & 20 & 7.3 & 6.7 & 11.2 \\
\hline 7 & 150 & 60 & 10 & 5 & 4.2 & 13.3 \\
\hline 8 & 150 & 60 & 15 & 5.8 & 4.5 & 15.6 \\
\hline 9 & 150 & 60 & 20 & 6.1 & 4.8 & 20.8 \\
\hline 10 & 200 & 40 & 10 & 9.4 & 9.1 & 6.9 \\
\hline 11 & 200 & 40 & 15 & 10.3 & 9.5 & 10.5 \\
\hline 12 & 200 & 40 & 20 & 10.7 & 10.1 & 8.1 \\
\hline 13 & 200 & 50 & 10 & 9.8 & 8.9 & 8.4 \\
\hline 14 & 200 & 50 & 15 & 11.4 & 10.6 & 7.6 \\
\hline 15 & 200 & 50 & 20 & 11.4 & 10.4 & 10.3 \\
\hline 16 & 200 & 60 & 10 & 12.5 & 10.6 & 11.0 \\
\hline 17 & 200 & 60 & 15 & 12.4 & 11.1 & 7.4 \\
\hline 18 & 200 & 60 & 20 & 11.8 & 10.4 & 8.2 \\
\hline 19 & 250 & 40 & 10 & 9.6 & 9.1 & 7.1 \\
\hline 20 & 250 & 40 & 15 & 10.7 & 10.0 & 5.0 \\
\hline 21 & 250 & 40 & 20 & 11.6 & 10.7 & 9.1 \\
\hline 22 & 250 & 50 & 10 & 13.1 & 11.9 & 9.5 \\
\hline 23 & 250 & 50 & 15 & 10.9 & 10.1 & 6.7 \\
\hline 24 & 250 & 50 & 20 & 11 & 10.2 & 7.9 \\
\hline 25 & 250 & 60 & 10 & 13.2 & 12.0 & 7.7 \\
\hline 26 & 250 & 60 & 15 & 12.8 & 12.0 & 10.5 \\
\hline 27 & 250 & 60 & 20 & 14.0 & 12.0 & 8.0 \\
\hline \multicolumn{4}{|c|}{ High Pressure Soxhlet (HPS) Extraction } & 5.8 & - & 8.8 \\
\hline \multicolumn{4}{|c|}{ Soxhlet n-Hexane Extraction } & 19.1 & - & 6.3 \\
\hline \multicolumn{4}{|c|}{ Perculator (Ethanol 96\%) } & 12.4 & - & 5.0 \\
\hline
\end{tabular}

by analysis of variance (ANOVA) are presented in (Table $7 \mathrm{a}$ and $7 \mathrm{~b}$ ). With 95\% confidence interval, only pressure affect the oil yield, while two others parameters (temperature and $\mathrm{CO}_{2}$ flowrate) have no significant effects $(P>0.05)$. The ANOVA results are in accordance with $\mathrm{S} / \mathrm{N}$ ratio that identify pressure as the main parameter.

Other extraction methods such as high pressure soxhlet with liquid $\mathrm{CO}_{2^{\prime}} \mathrm{n}$-hexane soxhlet extraction and percolation with ethanol were performed with yield $5.8 \%, 19.1 \%$ and $12.4 \%$, respectively (Table 6). Although, yield from $n$-hexane soxhlet extraction and percolation process higher than optimum results of SCFE- $\mathrm{CO}_{2}$ but the extract from both methods still contain organic solvent. Moreover, the final extract from these three different methods has lower content of thymoquinone compared to the SCFE- $\mathrm{CO}_{2}$ process, with concentration of $8.8 \mathrm{mg} / \mathrm{g}$ oil, $6.3 \mathrm{mg} / \mathrm{g}$ oil and $5.0 \mathrm{mg} / \mathrm{g}$ oil, respectively. Therefore, SCFE- $\mathrm{CO}_{2}$ seems to be a better alternative for Nigella sativa seeds since it offers the usage of non-toxic, non-explosive, environmental friendly, cost effective, time saving and selectivity-adjustable solvent in the extraction process. 
Salea et al. Biochemical Compounds 2013,

Table 7. Analysis of variance for Full Factorial Design: a) oil yield; b) thymoquinone.

\begin{tabular}{ccccccc}
\hline Source & DF & Seq SS & Adj SS & Adj MS & F & P \\
\hline Pressure & 2 & 73.916 & 73.916 & 36.958 & 16.18 & 0.000 \\
Temperature & 2 & 1.147 & 1.147 & 0.574 & 0.25 & 0.780 \\
CO flowrate & 2 & 0.227 & 0.227 & 0.114 & 0.05 & 0.952 \\
Residual Error & 20 & 45.692 & 45.692 & 2.285 & - & - \\
Total & 26 & 120.983 & - & - & - & - \\
Source & DF & Seq SS & Adj SS & Adj MS & F & P \\
Pressure & 2 & 121.460 & 121.460 & 60.730 & 9.95 & 0.001 \\
Temperature & 2 & 36.816 & 36.816 & 18.408 & 3.02 & 0.072 \\
CO2 flowrate & 2 & 4.442 & 4.442 & 2.221 & 0.36 & 0.699 \\
Residual Error & 20 & 122.069 & 122.069 & 6.103 & - & - \\
Total & 26 & 284.787 & - & - & - & - \\
\hline
\end{tabular}

\section{Conclusion}

The highest yield of SCFE- $\mathrm{CO}_{2}$ of Nigella sativa seeds oil using FFD was $12 \%$, with optimum conditions at 250 bar and $60^{\circ} \mathrm{C}$ with $\mathrm{CO}_{2}$ flowrate $20 \mathrm{~g} / \mathrm{min}$. While Taguchi method optimum condition was at $250 \mathrm{bar}, 50^{\circ} \mathrm{C}$ and $10 \mathrm{~g} / \mathrm{min}$ with oil yield $11.9 \%$. The difference between these two methods is insignificant $( \pm 0.1 \%)$. For highest TQ content, both methods gave similar optimum results at $150 \mathrm{bar}, 60^{\circ} \mathrm{C}$ and $20 \mathrm{~g} / \mathrm{min}$ with the value of TQ $20.8 \mathrm{mg} / \mathrm{ml}$. Hence, Taguchi method was able to simplify the experimental procedure without affecting the quality of results. The analysis of variance (ANOVA) from Taguchi method and full factorial design, indicate that pressure affect oil yield and TQ. The antibacterial activity Nigella sativa seeds oil from $\mathrm{L}_{9}$ Taguchi Method, shows inhibition i.e, 10\% for MRSA, 3\% for Stapylococcus aureus and 3\% for Bacillus subtilis but was unable to inhibit Escherichia coli $\mathrm{O} 157$ and Salmonella typhimurium even without oil dilution treatment.

\section{Competing interests}

The authors declared no conflict of interest with respect to the authorship and/or publication. All authors disclosed receipt of the following financial supports from PT Dexa Medica to conduct this study.

\section{Authors' contributions}

Each author provides substantial contributions to the concept and design of the work, conducting experimental procedures and validations, data acquisition, compilation, analysis, interpretation and draft manuscript preparation.

\section{Acknowledgement}

The authors also thank to Audrey Clarissa and Sherly Juliani for critical review of this manuscript.

Publication history

Received: 20-Mar-2013 Revised: 17-Apr-2013

Accepted: 15-May-2013 Published: 23-May-2013

\section{References}

1. Ismail M, Al-Naqeep G and Chan KW: Nigella sativa thymoquinonerich fraction greatly improves plasma antioxidant capacity and expression of antioxidant genes in hypercholesterolemic rats. Free Radic Biol Med 2010, 48:664-72. | Article | PubMed

2. Machmudah S, Shiramizu $Y$, Goto M, Sasaki M, Hirose T: Extraction of Nigella sativa L. using supercritical CO2: a study of antioxidant activity of the extract. Sep. Sci. Technol 2005, 40:1267-1275. | Article

3. Tiruppur Venkatachallam SK, Pattekhan H, Divakar S and Kadimi US: Chemical composition of Nigella sativa L. seed extracts obtained by supercritical carbon dioxide. J Food Sci Technol 2010, 47:598-605. | Article | PubMed Abstract | PubMed Full $\underline{\text { Text }}$

4. Burits $M$ and Bucar F: Antioxidant activity of Nigella sativa essential oil. Phytother Res 2000, 14:323-8. | Article | PubMed

5. Fararh KM, Shimizu Y, Shiina T, Nikami H, Ghanem MM and Takewaki T: Thymoquinone reduces hepatic glucose production in diabetic hamsters. Res Vet Sci 2005, 79:219-23. | Article | PubMed

6. Edris AE: Anti-cancer properties of Nigella spp. essential oils and their major constituents, thymoquinone and betaelemene. Curr Clin Pharmacol 2009, 4:43-6. | Article | PubMed

7. Ismail N, Ismail M, Al-Absi A, Al-Naqeeb G: Thymoquinone rich fraction from Nigella sativa and thymoquinone are cytotoxic towards colon and leukemic carcinoma cell lines. J. Med. Plants Res 2011, 5:3359-3366. | Website

8. Alhaj NA, Shamsudin MN, Zamri HF, Abdullah R: Extraction of essential oil from Nigella sativa using supercritical Carbon Dioxide: study of antibacterial activity. Am. J. Pharmacol. Toxicol 2008, 3:225-228. | Pdf

9. Alhaj NA, Shamsudin MN, Alipiah NM, Zamri HF, Bustamam A, Ibrahim S, Abdullah R: Characterization of Nigella sativa $L$. essential oil loaded solid lipid nanoparticles. Am. J. Pharmacol. Toxicol 2010, 5:52-57. | Article

10. Yi T, Cho SG, Yi Z, Pang X, Rodriguez M, Wang Y, Sethi G, Aggarwal $\mathrm{BB}$ and Liu $\mathrm{M}$ : Thymoquinone inhibits tumor angiogenesis and tumor growth through suppressing AKT and extracellular signal-regulated kinase signaling pathways. Mol Cancer Ther 2008, 7:1789-96. | Article | PubMed Abstract | PubMed Full Text

11. Parvardeh $S$, Fatehi $M$ : Effects of thymoquinone, the major constituent of Nigella sativa seeds, on the contractile responses of rat vas deferens. Pharm. Biol 2003, 41:616-621. I Pdf

12. Edris $A E$ : Pharmaceutical and therapeutic potentials of essential oils and their individual volatile constituents: a review. Phytother Res 2007, 21:308-23. | Article | PubMed

13. Reverchon E, De Marco I: Supercritical fluid extraction and fractionation of natural matter. J. Supercrit. Fluid 2006, 38:146166. | Article

14. De Castro LMD, Valcarcel M, Tena MT: Theoretical and Practical Aspects of Supercritical Fluid Extraction. Spinger-Verlag, Analytical Supercritical Fluid Extraction 1994, 79-163. | Article

15. McHugh MA, Krukonis VJ: Introduction. ButterworthHeinemann, Supercritical fluid extraction: Principles and practice 1986, 1-16. I Book

16. Dugo P, Mondello L, Bartle KD, Clifford AA, Breen D, Dugo G: Deterpenation of sweet orange and lemon essential oil with supercritical Carbon Dioxide using silica gel as an adsorbent. Flavour Frag. J 1995, 10:51- 58. | Article

17. Salgin $\mathrm{U}$, Korkmaz $\mathrm{H}$ : A green separation process for recovery of healthy oil from pumpkin seed. J. Supercrit. Fluid 2011, 58:239248. | Article

18. Ranjit R: Measurement of Quality. Van Nostrand Reinhold, A Primer on the Taguchi Method 1990, 19-28. I Book

19. Bahramifar $N$, Yamini $Y$, Shamsipur $M$ : Investigation on the 
supercritical carbon dioxide extraction of some polar drugs from spiked matrices and tablets. J. Supercrit. Fluid 2005, 35:205-211. | Article

20. Nuruddin MF, Bayuaji R: Application of Taguchi's approach in the optimization of mix proportion for microwave incinerated rice husk ash foamed concrete. IJCEE 2009, 9:121-129. | Pdf

21. Solati Z, Baharin BS, Bagheri H: Supercritical carbon dioxide (SC-CO2) extraction of Nigella sativa L. oil using full factorial design. Ind. Crop. Prod 2012, 36:519- 523| Article

22. Sodeifian G, Ansari K: Optimization of Ferulago Angulata oil extraction with supercritical carbon dioxide. J. Supercrit. Fluid 2011, 57:38-43. | Article

23. Machmudah S, Kawahito Y, Sasaki M, Goto M: Supercritical $\mathrm{CO}_{2}$ extraction of roseship seed oil: Fatty acids composition and process optimization. J. Supercrit. Fluid 2007, 41:421-428. I Article

24. Machmudah S, Kondo M, Sasaki M, Goto M, Munemasa J, Yamagata M: Pressure effect in supercritical $\mathrm{CO}_{2}$ extraction of plant seeds. J. Supercrit. Fluid 2008, 44:301-307. | Article

25. Li Q, Zhang Z, Zhong C, Liu Y, Zhou Q: Solubility of solid solutes in supercritical carbon dioxide with and without cosolvents. Fluid Phase Equilibr 2003, 207:183-192. | Pdf

\section{Citation:}

Salea R, Widjojokusumo E, Hartanti AW, Veriansyah $B$ and Tjandrawinata RR: Supercritical fluid carbon dioxide extraction of Nigella sativa (black cumin) seeds using taguchi method and full factorial design. Biochemical Compounds 2013, 1:1.

http://dx.doi.org/10.7243/2052-9341-1-1 